\title{
Local Interpretations of Degrowth-Actors, Arenas and Attempts to Influence Policy
}

\author{
Katarina Buhr ${ }^{1}$, Karolina Isaksson ${ }^{2,3, * \text { (D) }}$ and Pernilla Hagbert ${ }^{3}$ \\ 1 IVL Swedish Environmental Research Institute, Climate and Sustainable Cities Unit, \\ 10031 Stockholm, Sweden; katarina.buhr@gmail.com \\ 2 VTI, the Swedish National Road and Transport Research Institute, Division of Mobility, Actors and \\ Planning Processes, 10215 Stockholm, Sweden \\ 3 KTH Royal Institute of Technology, Department of Urban Planning and Environment, \\ 10044 Stockholm, Sweden; pernilla.hagbert@abe.kth.se \\ * Correspondence: karolina.isaksson@vti.se; Tel.: +46-766-334-328
}

Received: 3 May 2018; Accepted: 4 June 2018; Published: 6 June 2018

\begin{abstract}
During the last decade, degrowth has developed into a central research theme within sustainability science. A significant proportion of previous works on degrowth has focused on macro-level units of analysis, such as global or national economies. Less is known about local interpretations of degrowth. This study explored interpretations of growth and degrowth in a local setting and attempts to integrate degrowth ideas into local policy. The work was carried out as a qualitative single-case study of the small town of Alingsås, Sweden. The results revealed two different, yet interrelated, local growth discourses in Alingsås: one relating to population growth and one relating to economic growth. Individuals participating in the degrowth discourse tend to have a sustainability-related profession and/or background in civil society. Arenas for local degrowth discussions are few and temporary and, despite some signs of influence, degrowth-related ideas have not had any significant overall impact on local policy and planning. In practice, degrowth-interested individuals tend to adjust their arguments to the mainstream sustainability discourse and turn to arenas beyond the formal municipal organization when discussing transformative ideas about development, progress, and quality of life. Based on these findings, the conditions for a further integration of degrowth into local policy and planning are discussed. Suggested themes for further research are institutional change and the role of local politicians.
\end{abstract}

Keywords: degrowth; local growth; local policy; planning; radical sustainability

\section{Introduction}

The background to this paper is the conceptual development of degrowth and related debate among academics and activists in recent years [1-3]. Degrowth originated in the critique of economic growth that evolved with key works by Jackson [4], Latouche [5], and Victor [6], to mention but a few, breathing new life into the criticisms of growth expressed within the political and intellectual debate since at least the early 1970s [7]. The degrowth movement challenges the general focus on economic growth as an ubiquitous welfare measure in contemporary society and suggests a radically different way to think about welfare and prosperity. As stated by Demaria et al. [2] (p. 192), degrowth "is an attempt to re-politicise the debate on the much needed socio-ecological transformation, affirming dissidence with the current world representations and searching for alternative ones." Writers within the degrowth movement emphasize the importance of new trajectories, new politics, and new policy approaches to enact a transition to long-term sustainable development $[2,8]$. 
Knowledge production within research on degrowth has so far been characterized by a range of theoretically oriented contributions focusing on the idea or the concept itself [9-11] and suggesting alternative terms such as "a-growth" [12] or "steady-state economy" [13]. However, as highlighted by Joutsenvirta [14] and van den Bergh [12], there is a lack of in-depth understanding of how such alternative ideas for long-term sustainable development can be brought into practice. A significant proportion of the degrowth literature to date focuses on macro-level units of analysis [15]. There is a strand working on developing and analyzing concrete proposals for degrowth but, as stated by Cosme et al. [16], "the majority of degrowth proposals are national top-down approaches, focusing on government as a major driver of change, rather than local bottom-up approaches, as advocated by many degrowth proponents". In order to get a more complete picture, there is a need for a better understanding of how degrowth can be integrated at the local policy level. This requires identification of the dimensions of degrowth that local actors perceive to be relevant for local policy and of the experiences of actors engaged in attempts to influence local policy. Rather than focusing on single policy proposals (or combinations of these) and their contribution to degrowth, in this study we sought to gain insights into the institutional conditions that might affect the initiation and implementation of ideas and proposals related to degrowth in a real-world policy context.

The aim of the study was to explore interpretations of degrowth in a local setting and attempts to integrate degrowth ideas into local policy. This was done by seeking to identify the actors engaged in degrowth discussions and the arenas in which matters of degrowth are being discussed in a local setting, using a single-case study of the small town of Alingsås, Sweden, which was selected due to its stated interest in degrowth (see further below). The focus was on the local setting, including but not limited to the formal municipal organization. Ideas or activities were defined as degrowth-related if they recognized negative consequences of conventional economic growth as effects on either the environment or human wellbeing.

In the next section of this paper, we review existing literature on degrowth and select the specific dimensions of degrowth that we focus on in our study. We then describe the methodology and present the results of the case study on degrowth in Alingsås. This is followed by a discussion section in which we elaborate in particular on the conditions for institutional change, draw a number of conclusions based on the findings of the case study, and suggest promising avenues for future research in this area.

\section{Background: Degrowth in the Local Setting}

\subsection{Degrowth-A Call for a Radical Societal Transition}

In recent years, degrowth has evolved into a prominent theme for both grassroots activism and research $[2,8,16]$. However, degrowth is not a "new" idea, but a continuation of a long-established critique of the current development hegemony that was formulated already in the early 1970s, for instance by the Club of Rome [7] (cf. [2,6,8]). Contemporary degrowth researchers and activists argue that economic growth drives overconsumption and is the root cause of the profound ecological crisis occurring today, with resource depletion, climate change, biodiversity loss, and social inequalities [8].

In some of the more general discussions about degrowth, the term has been associated with sustainable development. While both degrowth and sustainability focus on the environmental crisis and social dimensions, degrowth ideas differs significantly from mainstream sustainability research by clearly criticizing the basic assumptions of the dominant economic paradigm [10]. In line with this, Kallis et al. [8] state that degrowth should not be viewed as less of the same, but rather about doing things differently. Degrowth is a call for a radical transition that encompasses the consolidation of other ideas about development, progress, and quality of life than those offered by focusing on conventional economic growth and development. It is about formulating individual and collective goals that can enable long lasting socio-environmental welfare over generations $[2,8,17]$. 


\subsection{Degrowth in Practice}

In concrete terms, degrowth is about the equitable downscaling of production and consumption levels to enhance ecological conditions and possibilities for human wellbeing [3]. It has also been described as societal change that is not primarily driven by a state or government, but rather evolves through grassroots movements since these types of initiatives are more likely to carry radical ideas and solutions that go beyond established ways of thinking and acting $[2,10,18]$.

In practice, policy initiatives for degrowth could consist of measures to reduce the negative externalities of growth politics and a questioning of many things that are taken for granted today, such as the level of mass consumption or the considerable transport of people and goods across the world [17]. Degrowth initiatives could also consist of initiatives aimed to develop alternatives to the mainstream economic and development agenda. One example could be initiatives that aim for a "relocalization" of the economy, i.e., for a strengthening of the connection between users and producers, for instance by cooperative arrangements [17], or other types of small scale and participatory alternatives in the areas of transport, food production, housing, recycling etc. [2].

Overall, degrowth leads to an increased focus on the local scale, such as grassroots or social movements [15,19], local businesses [20], or local currencies [21]. The degrowth research agenda also motivates a stronger focus on smaller towns and communities, which serve as a valuable contrast to mainstream sustainability research perspectives on trends related to centralization and urbanization [22]. However, there are many ways in which the degrowth agenda may be operationalized in practice [12], and little is known about the institutional conditions for advancing degrowth at the local level, especially in a non-crisis context.

The potential for degrowth to offer an alternative development trajectory, and a radically different political response than the current dogma of economism, has also been criticized. One such criticism regards to the avoidance among some degrowth scholars to more explicitly address the question of capitalism and the framing of institutional reforms within what is seen as a maintained capitalist rationale [23]. Particularly in relation to the focus assumed here on local institutions, the insufficiency of degrowth in outlining a more globally framed political "co-revolution" has been raised [23]. The "localist fetishism" of degrowth, envisioning an application of alternatives at the local and regional scale and as part of a cultural embeddedness, has moreover been criticized for what is perceived as a risk of enclosure and anti-democratic tendencies, and the reliance on an "elitist" voluntary approach [24]. These criticisms thus challenge the scope and political feasibility of degrowth in bringing about more far-reaching socio-ecological transitions with the urgency, yet democratic principles proposed as a main tenet in much of the degrowth literature.

\subsection{Analyzing Degrowth in a Local Institutional Context}

In this study, we examined degrowth in the local setting with a focus on actors and arenas within a geographical municipal area. Municipalities are vital actors in contemporary society, playing a key role for economic development and sustainability. Wätcher [25] argues that municipalities have an important role to play in degrowth and the transition towards sustainability, in their work as spatial planning institutions and actors in charge of community-based facilities.

In order to distinguish a discourse that goes beyond mainstream sustainability ideas and can be described as a degrowth discourse, we drew on the qualitative discourse analysis of contemporary classics in the degrowth literature by Haapanen and Tapio [26]. This means that we identified ideas or activities as degrowth-related if they recognize negative consequences of economic growth as effects on either the environment or human well-being, which Haapanen and Tapio [26] classify as "growth as a phenomenon". This includes, e.g., the role of extensive consumption in resource depletion, climate change, or people's happiness.

In order to explore the interpretation of degrowth in a local setting and attempts to integrate such ideas into local policy, we focused on the institutional context. Building on institutional theory $[27,28]$, any individual or organizational behavior needs to be seen in its institutional context, understood as a 
social system comprised of values, norms, and taken-for-granted assumptions which prescribe the kind of behavior deemed appropriate $[28,29]$. An institutional perspective on degrowth is advocated by Joutsenvirta [14] (p. 24) as "a useful approach to investigate important dynamics and challenges involved in the radical social change aspired by degrowth". Recognizing the role of the institutional context is important in understanding how organizations, including municipal authorities, behave, the social space within which individuals have to act, and how change can occur. Institutions have underlying logics—socially constructed broader belief systems—of which the capitalist market is one [30]. While institutions regulate what is seen as appropriate behavior, a significant proportion of the literature on institutional theory shows how institutions can change, and the role of actors in doing so, using concepts such as institutional change (e.g., [31]) or institutional entrepreneurship [32,33]. As argued by Joutsenvirta [14], institutional change will be necessary for degrowth ideas to have a large-scale impact on everyday politics.

\section{Materials and Methods}

Empirical material for our analysis was obtained in a single-case study of the small town of Alingsås, Sweden. While Sweden is not among the countries considered as pioneers in the degrowth community (cf., [34]), degrowth ideas have gained a foothold among academics and activists alike during recent years (e.g., [35-37]). This makes Sweden an interesting case for analyses of degrowth in a non-crisis context.

Alingsås municipality is located in Västra Götaland County in western Sweden and consists of the city center and the surrounding countryside with a few small villages. The municipality has grown steadily in recent decades, from approximately 26,500 in 1970 to 40,000 inhabitants in 2016 [38]. The Swedish Association of Local Authorities and Regions categorizes Alingsås as a "commuting municipality near large cities", meaning that more than 40 per cent of the working population commute to work in a large city or a municipality near a large city $[39,40]$. The main commuting destination is Gothenburg, Sweden's second largest city. Alingsås is well connected by rail and road, as it lies on the main route between Stockholm and Gothenburg. As part of the Gothenburg Metropolitan Area, Alingsås has committed itself to city planning that strengthens and develops this region. This means that when Alingsås is planning new residential buildings and businesses, priority must be given to locations near existing public transport routes.

The main reason for selecting Alingsås as the case for our research is that the municipality has a stated interest in degrowth. This is seen for instance through specific formulations in some of main policy and planning documents and is also manifested through activities such as "Future Week" (see further below). Furthermore, there is an active civil society with a pronounced engagement in degrowth ideas and in general sustainability matters. At the same time, however, the close links to the regional development plans for the larger Gothenburg area mean that the degrowth ideas must co-exist with a more mainstream development direction.

In the literature, single-case studies are described as a valuable approach for investigating complex phenomena in greater depth than would be permitted by multiple case studies and more general approaches [41]. We identified Alingsås as a relevant case to study not because it is representative, but because it has the potential to provide an empirically grounded illustration of our research topic, namely interpretation of degrowth in a local setting.

The case study of Alingsås was conducted through a qualitatively driven approach, building on interviews and analyses of official documents. This was complemented with observations of the local event "Future Week", which is a key arena for discussing issues related to degrowth and long-term sustainable development in Alingsås.

The interviews were conducted with the aim of understanding the reasoning and actions of key individuals with the potential to influence local policy and planning by introducing degrowth-related ideas, rather than those of the average citizen. The interviews were held in two rounds. The first set of interviews was with civil servants working for Alingsås municipality with key positions in 
either local planning and development or sustainable development. These interviewees were selected in order to determine the current understanding of growth and degrowth in the formal municipal organization and included the Head of Development, the project managers for the Comprehensive Plan and the local Growth Program, the environmental strategist, and the energy and climate advisor. The Comprehensive Plan is a key document for any Swedish municipality, guiding the long-term development of land use. The local Growth Program in Alingsås was interesting for our research, both due to its status as a key steering document and its section that problematizes local growth. We posed open-ended questions about local growth, degrowth, and sustainability. We also asked the interviewees to identify individuals who are influential in discussing degrowth locally.

The second round of interviews was held with these degrowth-interested individuals, who carried ideas that could potentially allow degrowth to make an impact on local policy and planning. Some of these interviewees were working in municipal companies (when municipal affairs like energy or housing are managed by a municipally owned and controlled company). Others were working in civil society. In interviews we examined their background, motives, reasoning, where they bring up degrowth discussions and how these discussions are carried out, especially in relation to local policy and planning.

Altogether, we conducted 10 semi-structured interviews with a total of 11 respondents (two respondents were present in one of the interviews). Eight interviews were carried out face-to-face, while two respondents preferred telephone interviews. All interviews were transcribed to allow for a thorough analysis.

The two rounds of interviews contributed complementary insights to our overall objective of understanding the local interpretation of degrowth and its potential impact (for a full list of interviewees, see Appendix A).

Official policy documents-including the local Growth Program and the two most recent Comprehensive Plans-constituted another important source of data. Moreover, we attended a number of events at "Future Week" in Alingsås on 4-8 April, 2016, to get a broader understanding of how degrowth-related matters are being discussed locally. All data were analyzed in an iterative manner whereby the empirical data were consulted repeatedly as new findings emerged.

\section{Results}

\subsection{Empirical Background: Sustainability and Growth in Swedish Municipalities}

In Sweden, municipalities are responsible for "matters relating to the inhabitants of the municipality and their immediate environment" [42]. This means that municipalities are legally obliged to take considerable responsibility for social welfare and for a number of environmental issues such as waste management and water supply. In practice, many municipalities take greater responsibility than the law prescribes for social, ecological, and economic sustainable development, and for issues such as culture and leisure activities and climate change.

Swedish municipalities are responsible for the planning of land use and water within their territory, and regional or national authorities have no formal power over local development decisions as long as they do not violate national regulations [43]. This means that municipalities play an important role in envisioning the good life and in developing visions and strategies for the future [44].

Economic growth has long been a central issue for many Swedish municipalities, not least since it is considered to be a key factor for maintaining a robust local tax base, which is important for funding key welfare services such as schools, health and social care, and social services [45]. However, there are often a range of interpretations of what growth entails and why it is important, depending on local factors such as differences in population development, geographical location, economic structure, historical context, etc. The most common perspectives are currently population growth and increased employment rate and income among the local population [46]. Arena for Growth [46] suggests a range of indicators for growth in Swedish municipalities, including employment (degree and development), 
local businesses, education level, payroll development, the municipality's financial results, housing prices, tax capacity, sales in fast-moving and durable consumer goods, and demographic statistics. The mainstream view is that 'more is better'.

\subsection{Case Study}

\subsubsection{The Meaning of Growth and Its Critique}

In order to grasp how degrowth is interpreted locally, we must first understand what it seeks to oppose, i.e., the local meaning of growth. As shown in previous studies (e.g., [45]), the meaning of growth may differ significantly between municipalities. Thus, it was important for us to distinguish aspects of growth that are particularly prominent in the local discussions in Alingsås, areas that are seen as desirable to grow, and why.

At the core of city planning in Alingsås is the idea of population growth. The municipality has developed a vision that "Alingsås has 42,000 inhabitants in the year 2019" and this vision "is present as a background in every decision that is made" [47]. As the Head of Development put it: "We have an entire hierarchy of goals, and on top is our vision of population growth" (Interview 4). The projected population growth is also a critical aspect that guides the new Comprehensive Plan of Alingsås (Interview 3). One civil servant explained: "When talking about growth in Alingsås, at least in the City Hall, it is primarily the number of people that we are talking about" (Interview 5). The idea of population growth has been around for a long time (Interview 4), but it has changed slightly over time. The previous Comprehensive Plan for Alingsås, from 1998, stated that "the city planning shall provide conditions for a calm and continuous population growth" [48]. In contrast to the present debate, the previous plan emphasized that "the small town character shall be preserved" and that "the development of new buildings shall be delimited" [48] (p. 13).

In November 2015, the City Council of Alingsås adopted a local Growth Program for the period 2016-2025 [49]. This program aims to provide an overall picture of ongoing development initiatives in Alingsås, including public and private projects, from the municipality's point of view. The Growth Program is-based upon national and regional guidelines, as well as adopted municipal guidelines, and it sets priorities for local city planning and investments. The Growth Program was developed due to the generally perceived lack of a document describing community development from an overarching perspective (Interview 2). The Growth Program was developed by the municipal administrations responsible for city planning (the Planning Office), and the technical managers responsible for streets, parks, nature, water and sewage, and waste management, in dialogue with the City Management (Interview 2). Hence, it provides clues about how growth is interpreted by civil servants in Alingsås.

The Growth Program takes the population target of 42,000 inhabitants by 2019 as a point of departure and emphasizes the need for more residential buildings in order to meet this target. The strategist for urban planning, who did much of the work with the Growth Program, explained: "It is about achieving population growth. That is what is put in the concept of growth" (Interview 2). The strategist also explained that an increased population means that more people pay local taxes, which allows the municipality to provide more welfare services. An increased population can also be expected to increase demand for goods and services from local businesses and increase the availability of appropriate manpower for local businesses. The city plans to develop new residential areas so that people have places to live, but also in order to grow businesses and the number of jobs. In particular, residential areas are planned close to the central station, in order to facilitate further commuting. The Growth Program also highlights development of local business, tourism, culture and leisure activities.

Thus, although the Growth Program primarily focuses on population growth, it is also clearly associated with ideas related to mainstream economic growth (more tax income, more welfare, an increased demand for goods and services, etc.), in line with previously mentioned indicators 
for local growth [46]. The Growth Program represents a perspective according to which growth is projected as a natural starting point for the municipality as a welfare producer.

Interestingly, however, the Growth Program [49] (p. 8) also includes a section that explicitly problematizes growth. For instance, it is recognizes that:

"In the efforts towards sustainable development, population growth is an important, yet not unproblematic, tool".

Having elaborated on economic development, the document continues:

“This development is not without conflicts. Population growth presumes increased travel within the region and significant construction of residential buildings and infrastructure. For a wide range of factors, such as greenhouse gas emissions, loss of biodiversity and negative impact on marine ecosystems, it is obvious that economic growth goes hand in hand with increased environmental pressure". [49] (pp. 8-9)

The Growth Program also includes a definition of sustainability which describes economic development as a means to achieve the objective of social sustainability, while ecological sustainability is a precondition to get there:

"Whether growth is compatible with sustainable development is not obvious, but it depends on how growth happens". [49] (p. 9)

The project manager for the Growth Program explained that the critical reflections on GDP growth was the outcome of a discussion that originally was initiated by the officials, on how the municipality should relate to growth. Their discussion led to the fact that also the local politicians saw the relevance of acknowledging goal conflicts and negative consequences for sustainability (Interview 2). Thus, both officials and politicians at the local level see reasons to criticize the growth idea.

Broadening the perspective outside the formal municipal organization, there is also a vivid debate in Alingsås regarding population growth and its impact on the city's identity. This type of criticism relates to resistance to changing the city's small-town identity (Interview 1; [50]). This view is driven by a few local politicians (Interview 1) and there are grassroots initiatives that aim to preserve the picturesque town center with low-rise, old, wooden buildings [50].

In sum, growth ideals are highly present in the formal municipal organization. The fundamental aspect of growth is a growing population, and concerns about growth relate mainly to the potential impact of population growth, and associated economic growth, on the environment and the city's identity. While this debate relates to sustainability issues, it stays within a fairly mainstream and conventional approach in which the conventional idea of economic growth is not truly challenged. In the words of one respondent: "I have not heard one single politician in Sweden say that they do not want their city to grow (... ) in terms of population, infrastructure, employment, consumption, and so on" (Interview 8). However, if one broadens the perspective to outside the formal policy and planning arena, there is also a debate about growth in Alingsås which challenges the fundamental ways of thinking about economic and social prosperity.

\subsubsection{Actors for Degrowth}

In the interviews, it was possible to identify a handful of enthusiastic individuals in Alingsås who actively discuss and promote ideas related to degrowth, for instance by considering the negative consequences of economic growth in environmental or social terms. Throughout their interviews, they criticized the dominance of mainstream views within the city organization and frequently highlighted the environmental problems caused by the quest for continuous economic growth in a world with finite resources: 
"It is simple math ( . . ) If we double the world economy this much in this many years, we need this much natural resources. Can we do that? No, we can't.". (Interview 7)

One respondent described the formal municipality of Alingsås as having particularly committed people working in the area of sustainability (Interview 7). What these individuals have in common is (1) a profession that focuses on environmental, energy, or sustainability issues; and (2) a background, or ongoing engagement, in civil society organizations that focus specifically on environmental issues and/or degrowth. These individuals generally know each other and refer to each other as "we" or "us" (Interviews 1, 7, 9).

Some of these individuals work for the City Council, yet have close links to civil society. In the words of two interviewees:

"The corridor where I work is no regular corridor ( . . ) they have ideas that go very much in hand with the transition movement." (Interview 5) and "It is almost like the municipality runs the local transition movement ( . . ) and there is a bottom-up pressure too.". (Interview 4)

Other individuals who are engaged in the local attempts to promote degrowth ideas are employed at municipal companies such as Alingsåshem (housing) and Alingsås Energi (energy). In addition, Alingsås is home to Passivhuscentrum Västra Götaland, a public environmental center that promotes energy-efficient building and renovation, mainly through passive houses. Passivhuscentrum has a pioneering position in this technology and has attracted employees that engage in and initiate activities for sustainability:

"It feels like many of the initiatives come from those who primarily own the question, i.e., the municipal companies ( . . ) If you look at the municipal organization as a whole, there are many enthusiasts working here." (Interview 6)

Several of these individuals have been involved in starting up local civil society organizations. Some of them gave up their civil society or political missions when they accepted their current professional role (Interviews 1, 7). In addition, several individuals are, or have been, engaged in civil society organizations such as Omställning Alingsås (Transition Alingsås), the local branch of Omställningsrörelsen, which is a Swedish movement with inspiration from the international Transition Network. Omställning Alingsås has been described as lively and locally influential (Interviews 4, 10), with people who focus on practical work in order to make a change and increase the resilience of local society (Interview 9). Some are also involved in Steg 3 (Interview 7), a Swedish informal network that explicitly seeks to bring attention to the shortages and dilemmas of economic growth [51].

\subsubsection{Arenas for Degrowth}

One of the arenas where degrowth discussions take place locally is an event called "Future Week" (Interview 1). Bonnier [50] examined "Future Week" in Alingsås in 2016, and described it as "a meeting place for locals interested in sustainability", where they exchange ideas and inspire each other by showing good examples of local transitions within the municipality. Those who attend "Future Week" are mainly individuals with a strong interest in sustainability. Some visitors are actively engaged in the local transition movement, Omställning Alingsås.

Omställning Alingsås has also arranged conversations with politicians and has posed questions through the local media, to bring up issues related to degrowth (Interview 9). Another informal and temporary arena for Omställning Alingsås is events such as flea markets held at a central location, where the organization takes the opportunity to present its message to people it would not have reached otherwise (Interviews 5, 9). Moreover, since many of the key individuals know each other, informal discussions also take place informally. However, several interviewees reported that they lack formal arenas to discuss these things freely: "To be able to problematize ( . . ) there is a lack of forums to have a serious discussion about it" (Interview 6). 
Altogether, the interviews give a clear picture that there are currently no formal arenas where issues related to degrowth are discussed in any extensive or in-depth manner. Several of the interviewees reported that they choose other arenas outside the municipality to vent their radical ideas and get things done:

"It is really inspiring to be part of regional networks / ... / There are so many talented, committed people in other municipalities too. In addition, then it is very nice to relax with them and feel that you do not have to explain everything / . . / we all have similar experiences. We want so much. Sometimes you get there and sometimes not" (Interview 1)

"I direct my energy elsewhere" ( . . ) Having discussions with politicians who really have no time to reflect, but must take urgent decisions every day, I feel is pointless." (Interview 9)

\subsubsection{Attempts to Influence Policy}

The interviewees reported that the discussions on questioning economic growth in general have not yet had any significant impact on local policy and planning in Alingsås, with a few exceptions (Interviews 1,9). One example is an appendix to the Local Energy Plan 2011-2013, where a consultant provided an overview of how Alingsås may be affected by "peak oil" [52]. "Peak oil" is a prominent topic of degrowth (e.g., [4]) and one interviewee described the inclusion of the appendix as an event that gave hope for increased awareness among local politicians (Interview 9). However, problematizing economic growth is mainly done in the arenas described above, such as "Future Week" and within Omställning Alingsås (Interviews 1,10). Although some individuals have professional positions that drive environmental and sustainability issues and potentially could challenge the prevailing policy and planning, they feel that either it lies outside their mandate to drive degrowth ideas within their professional role (Interview 7) or that challenging the norm of economic growth is a too large step to take:

"If anyone were to question growth, one would still, sadly, be dismissed instantly as totally unrealistic. While in fact, one just wants to problematize our consumption habits, and talk about how we want to live our lives." (Interview 1)

The interviewees also reported that most people do not see growth as a problem-it is a "non-issue" (Interview 1):

"People do not problematize that much, so far. Instead, they assume that growth is good for the municipality. And then it is up to us environmentalists to do that in a good way" (Interview 6).

While there may be insights about global problems, these are not seen as a matter for Alingsås: "People rarely link the global problem of growth with municipal growth. Those kinds of discourses are very rare in a municipal perspective, among local politicians in Sweden. They never recognize global population growth or the limits of natural resources." (Interview 7).

The norms described by the interviewees represent institutional conditions that prescribe what is appropriate to do and say. The dominant ideas about how Alingsås should develop (Interview 3) are in many ways typical of the contemporary Swedish urban planning discourse, including ideals about increased population [53] and sustainability [44]. Although the Growth Plan in Alingsås contains some criticism of growth in itself, several interviewees reported that economic growth is what is desirable:

“There are many people who don't understand what I am talking about. 'But we have to have growth!' is a fairly common comment. Another common comment is: 'Do you want us back to the Stone Age?'" (Interview 9). 
Previous studies confirm that the norm of economic growth is indeed highly present in Sweden [35-37,54]. The scope for criticizing growth may even be limited in environmental civil society organizations; Steg 3 was a result of people's frustration that they could not vent their criticism of economic growth and gross domestic product (Interview 7).

Nevertheless, several interviewees described strategies through which they question economic growth as a superior and desirable objective. What these strategies have in common is that they can be described as "undercover" activities, in which there is no explicit mention of degrowth. Several interviewees highlighted the importance of semantics and pointed out that terms other than growth or degrowth have been considered, to avoid "scaring people off" (Interviews 1, 9). Instead, they "sneak in the message", e.g., to managers, politicians, and citizens, employing a number of strategies:

- Events on related topics: For example, two municipal officers organized environmental training for a large number of municipal officers in Alingsås, where they included degrowth perspectives such as "planetary boundaries" and the environmental pressure that follows from increased consumption (Interviews 1,5). This was described as one of the few occasions where this was suitable to bring up:

"We can be really frank about how bad things really are." (Interview 5), and:

"When you lecture, you have control. But if one, all of a sudden in another context, were to start talking about 'well, you know economic growth, it is not all good, there are drawbacks'. No, that would only turn out wrong. I choose my occasions." (Interview 1).

Other examples include the abovementioned flea markets run by Omställning Alingsås (Interview 9) and cultivation classes (Interview 10), which try to present messages related to degrowth. Yet another example is to invite Swedish degrowth proponents, such as David Jonstad, to give talks at "Future Week".

- Participation in research projects: Efforts from a civil servant resulted in the political decision that Alingsås would participate in a Swedish research project called "Beyond GDP growth", in which the main focus is to investigate what happens if growth is no longer a given, or necessarily desired. The justification stated in the minutes of the municipality board meeting is that it raises opportunities for Alingsås to influence growth research in an early stage, gain knowledge of the issue and input into the municipality's own work on shaping the municipality's vision and future [55]. As the initiator of participation by Alingsås put it:

"This research project- to get the opportunity to discuss with managers and politicians and make them aware that some form of criticism of the concept of growth existsit was just too good an opportunity ..." (Interview 1).

- Informal discussions with local politicians and civil servants: One municipal officer described how he "takes every chance" (Interview 1) to raise radical sustainability messages. Omställning Alingsås invites politicians to informal discussions over a cup of coffee, rather than submitting motions to the municipal council (Interview 9). Individuals working for the municipal companies do not prepare motions either, but rather believe in informal discussions:

"It is about one-to-one talks with anyone. Regardless of whether it is a politician in the party you belong to, or other parties, or civil servants." (Interview 7).

\section{Discussion}

This study explored the interpretations of degrowth in a local setting and attempts to integrate such ideas into local policy. Through a case study, we distinguished two different, yet interrelated, local growth discourses in Alingsås: one that relates to population growth and one that relates to economic growth. There is local criticism to both these understandings of growth. The critique 
of economic growth as an overarching objective clearly relates to the degrowth movement. Local interpretations of degrowth in Alingsås include questioning e.g., whether the municipality should promote increased consumption, given its negative social and environmental impact; whether the city should be developed to encourage an increased share of commuters among the population, which results in increased environmental pressure; and to what extent the municipality should be dependent on fossil fuels. Despite these elements of degrowth ideas, the formal municipal organization has not settled on a clear stance on degrowth related to development in Alingsås.

We also found that there are a number of engaged individuals in Alingsås who actively discuss degrowth ideas. What these individuals have in common is: (1) a profession that focuses on environmental, energy, or sustainability issues; and (2) a background, or ongoing engagement, in civil society organizations that focus on degrowth or more general environmental issues. These are actors are often highly engaged, through their work or involvement in different types of networks, but they lack formal power in the municipal decision-making process. They may have a stated ambition to influence local policy, but encounter difficulties when they aim for continuity and a clear impact. Their narratives revealed the current difficulty in launching degrowth ideas in a systematic way. They reported that their ideas are not necessarily heard, which means that they tend to adapt their arguments to the mainstream sustainability discourse in the formal municipal organization and choose other arenas for discussing more radical sustainability issues. Arenas for local degrowth discussions are few and temporary, such as "Future Week".

Even though there are some people in Alingsås who support the idea of degrowth, these ideas have not yet had any significant impact on local policy and planning. There are some signs of incipient influence, e.g., the section of the local Growth Program that problematizes growth and the Peak Oil appendix to the Local Energy Plan. The fact that the municipality allows civil servants to spend time and other resources on "Future Week" and other events such as in-house environmental training, and on participation in a research project that questions growth, shows that the formal municipal organization recognize the potential relevance of degrowth-related ideas, even when they might not be explicitly referred to in terms of degrowth. Yet, the dominant norms of economic growth that can be expected in any municipality are also highly present. Although civil servants have the potential to act as inside activists (cf. [56]) and support an active local transition movement, these individuals act within the scope of the overarching norms and values about how the municipality should develop. Thus, there is a lot more to be done before degrowth-related ideas can be fully integrated and recognized as real alternatives, that can influence the long-term strategic direction of the municipality.

These findings shed light on a question raised by previous researchers, namely the institutional conditions that would allow degrowth ideas to be integrated into real world policy and planning. As shown in our analysis, actors' opportunities to diverge from the established institutional context, which consists of prevailing norms, values, and regulations about the type of development that is desirable, are limited. This is also the main explanation, as we see it, for why individuals who harbor radical ideas still adapt their work to a mainstream sustainability discourse.

As we see it, one key factor for integrating degrowth in the local setting would be to establish a more developed and concrete understanding of what degrowth can entail in a particular municipality, in this case Alingsås. The current Growth Program indicates that there is some criticism of mainstream development ideas among politicians and planners in the municipality. However, this criticism is not very strong, but rather low-key and fragmentary and it does not lead to the formulation of any alternative ways of thinking and acting regarding the development of the municipality. Given the advantage of the already established mainstream perspectives, it will remain difficult to develop a more thorough degrowth-oriented agenda at the local level as long as it is done primarily through critical formulations in policy documents. Based upon what we have seen in the case of Alingsås, and the promising examples of the Future Week and other arenas that provide space for formulating concrete alternatives, we conclude that a key strategy for integrating degrowth-related ideas at the local arena 
could be to put more effort into this type of initiatives. Developing concrete projects and experiments gives direct results in terms of an empirically grounded, concrete experience of degrowth in practice. If these initiatives prove to work, they could provide a basis a more general discussion of what a degrowth-oriented approach may mean for the strategic direction of the municipality. This suggestion is closely related to ideas that has been developed in the literature on climate change mitigation, where urban experiments have been a central theme in recent years of research [57].

A critical dimension for local integration of degrowth ideas is to link these ideas more closely to the established institutional context. Actors with formal power, such as elected politicians, need to be knowledgeable and actively support degrowth ideas if they are to be consolidated in the local institutional context. A final reflection from our work in this study is that there is a need for future research to explore the role of local politicians, and the challenges that they face when trying to work with degrowth-related ideas. How can politicians take radical decisions towards sustainability in a democratic manner, with support from other parties and local citizens? What is the role of semantics in gaining support for such decisions? A thorough understanding of present conditions for local politics is fundamental to identifying how institutional change can occur and pave the way for a sustainable transition.

Author Contributions: The overall design of the study and the empirical work was performed by K.B., who is the main author of the text in all its parts. K.I. and P.H. were involved in drafting significant parts of the text, with specific focus on the theoretical framing and concluding discussion.

Acknowledgments: This research was carried out within the project "Beyond GPD Growth: Scenarios for Sustainable Communities" funded by the Swedish Research Council for Environment, Agricultural Sciences and Spatial Planning (Formas), Grant number 2013-1842. The authors wish to thank Elin Bonnier for her input on the work in "Future Week", as well as all interviewees and two anonymous reviewers whose comments helped us to improve the paper.

Conflicts of Interest: The authors declare no conflict of interest. The funding agency had no role in the design of the study; in the collection, analyses, or interpretation of data; in the writing of the manuscript, and in the decision to publish the results.

\section{Appendix A. Overview of Interviews}

\begin{tabular}{|c|c|c|c|c|c|c|}
\hline ID & Type of Actor & $\begin{array}{l}\text { Organizational } \\
\text { Belonging }\end{array}$ & Role & $\begin{array}{c}\text { Date of } \\
\text { Interview }\end{array}$ & $\begin{array}{c}\text { Mode of } \\
\text { Interview }\end{array}$ & $\begin{array}{l}\text { Selection } \\
\text { Criteria }\end{array}$ \\
\hline 1 & Civil servant & City Council & Environmental strategist & 1 March 2016 & Face-to-face & MR-SD, DII \\
\hline 2 & Civil servant & City Council & $\begin{array}{l}\text { Project manager for the } \\
\text { Growth Program and } \\
\text { strategist for } \\
\text { urban planning }\end{array}$ & 1 March 2016 & Face-to-face & MR-PD \\
\hline 3 & Civil servant & $\begin{array}{l}\text { The Planning } \\
\text { Office }\end{array}$ & $\begin{array}{l}\text { Project manager for the } \\
\text { Comprehensive Plan }\end{array}$ & 1 March 2016 & Face-to-face & MR-PD \\
\hline 4 & Civil servant & City Council & $\begin{array}{l}\text { Head of Development and } \\
\text { Acting Head of Alingsås } \\
\text { Business Center }\end{array}$ & 1 March 2016 & Face-to-face & MR-PD \\
\hline 5 & Civil servant & City Council & $\begin{array}{c}\text { Energy and } \\
\text { Climate Advisor }\end{array}$ & 4 May 2016 & Telephone & MR-SD, DII \\
\hline 6 & $\begin{array}{l}\text { Municipal } \\
\text { company }\end{array}$ & Alingsås Energi & Sustainability Controller & 4 April 2016 & Face-to-face & MR-SD, DII \\
\hline 7 & $\begin{array}{l}\text { Municipal } \\
\text { company }\end{array}$ & Passivhuscentrum & Head of Operations & 5 April 2016 & Face-to-face & MR-SD, DII \\
\hline 8 & $\begin{array}{l}\text { Municipal } \\
\text { company }\end{array}$ & Passivhuscentrum & $\begin{array}{l}\text { Project managers } \\
\text { (two interviewees) }\end{array}$ & 4 May 2016 & Face-to-face & MR-SD, DII \\
\hline 9 & Civil society & $\begin{array}{l}\text { Omställning } \\
\text { Alingsås }\end{array}$ & Founder, member & 22 April 2016 & Telephone & LCS, DII \\
\hline 10 & Civil society & Studiefrämjandet & $\begin{array}{c}\text { Responsible for areas } \\
\text { nature, animals, } \\
\text { environment, sustainable } \\
\text { development and asylum }\end{array}$ & 5 April 2016 & Face-to-face & LCS, DII \\
\hline
\end{tabular}

Selection criteria. MR-PD: Municipal representative: key position in local planning and development; MR-SD: Municipal representative: key position in sustainable development; DII: Degrowth-interested individual; LCS: Local civil society representative. 


\section{References}

1. Cattaneo, C.; D’Alisa, G.; Kallis, G.; Zografos, C. Degrowth futures and democracy. Futures 2012, 44, $515-654$. [CrossRef]

2. Demaria, F.; Schneider, F.; Sekulova, F.; Martinez-Alier, J. What is Degrowth? From an Activist Slogan to a Social Movement. Environ. Values 2013, 22, 191-215. [CrossRef]

3. Schneider, F.; Kallis, G.; Martinez-Alier, J. Crisis or opportunity? Economic degrowth for social equity and ecological sustainability. Introduction to this special issue. J. Clean. Prod. 2010, 18, 511-518. [CrossRef]

4. Jackson, T. Prosperity without Growth: Economics for a Finite Planet; Earthscan: London, UK, 2009.

5. Latouche, S. Farewell to Growth; Polity Press: Cambridge, UK, 2009.

6. Victor, P. Managing without Growth: Slower by Design, Not Disaster; Edward Elgar: Cheltenham, UK, 2008.

7. Meadows, D.; Meadow, D.; Randers, J.; Behrens, J. The Limits to Growth: A Report for the Club of Rome's Project on the Predicament of Mankind; Earth Island: London, UK, 1972.

8. Kallis, G.; Demaria, F.; D'Alisa, G. Degrowth. A Vocabulary for a New Era; Routledge: Abingdon, UK, 2014.

9. Kallis, G. In defense of degrowth. Ecol. Econ. 2011, 70, 873-880. [CrossRef]

10. Martinez-Alier, J.; Pascual, U.; Vivien, F.-D.; Zaccai, E. Sustainable de-growth: Mapping the context, criticisms and future prospects of an emergent paradigm. Ecol. Econ. 2010, 69, 1741-1747. [CrossRef]

11. Drews, S.; Antal, M. Degrowth: A "missile word" that backfires? Ecol. Econ. 2016, 126, 182-187. [CrossRef]

12. Van den Bergh, J. Environment versus growth-A criticism of "degrowth" and a plea for "a-growth". Ecol. Econ. 2011, 70, 881-890. [CrossRef]

13. Kerschner, C. Economic de-growth vs. steady-state economy. J. Clean. Prod. 2010, 18, 544-551. [CrossRef]

14. Joutsenvirta, M. A practice approach to the institutionalization of economic degrowth. Ecol. Econ. 2016, 128, 23-32. [CrossRef]

15. Bloemmen, M.; Bobulescu, R.; Tuyen Le, N.; Vitari, C. Microeconomic degrowth: The case of Community Supported Agriculture. Ecol. Econ. 2015, 112, 110-115. [CrossRef]

16. Cosme, I.; Santos, R.; O'Neill, D.W. Assessing the degrowth discourse: A review and analysis of academic degrowth policy proposals. J. Clean. Prod. 2017, 149, 321-334. [CrossRef]

17. Latouche, S. Degrowth. Editorial. J. Clean. Prod. 2010, 18, 519-522. [CrossRef]

18. Ayres, R.U. Sustainability economics: Where do we stand? Ecol. Econ. 2008, 67, 281-310. [CrossRef]

19. Alexander, S. Voluntary Simplicity and the Social Reconstruction of Law: Degrowth from the Grassroots up. Environ. Values 2013, 22, 287-308. [CrossRef]

20. Kostakis, V.; Latoufis, K.; Liarokapis, M.; Bauwens, M. The convergence of digital commons with local manufacturing from a degrowth perspective: Two illustrative cases. J. Clean Prod. 2016. [CrossRef]

21. Dittmer, K. Local currencies for purposive degrowth? A quality check of some proposals for changing money-as-usual. J. Clean. Prod. 2013, 54, 3-13. [CrossRef]

22. Newman, P. The environmental impact of cities. Environ. Urban 2006, 18, 275-295. [CrossRef]

23. Foster, J.B. Capitalism and Degrowth-An Impossibility Theorem. Mon. Rev. 2011, 62, 26-33. [CrossRef]

24. Romano, O. How to rebuild democracy, re-thinking degrowth. Futures 2012, 44, 582-589. [CrossRef]

25. Wätcher, P. The Impacts of Spatial Planning on Degrowth. Sustainability 2013, 5, 1067-1079. [CrossRef]

26. Haapanen, L.; Tapio, P. Economic growth as phenomenon, institution and ideology: A qualitative content analysis of the 21st century growth critique. J. Clean. Prod. 2016, 112, 3492-3503. [CrossRef]

27. DiMaggio, P.J.; Powell, W.W. (Eds.) The New Institutionalism in Organizational Analysis; The University of Chicago Press: Chicago, IL, USA, 1991.

28. Greenwood, R.; Oliver, C.; Sahlin, K.; Suddaby, R. The SAGE Handbook of Organizational Institutionalism; SAGE: London, UK, 2008.

29. Suddaby, R. Challenges for institutional theory. J. Manag. Inq. 2010, 19, 14-20. [CrossRef]

30. Friedland, R.; Alford, R. Bringing Society Back in: Symbols, Practices, and Institutional Contradictions. In The New Institutionalism in Organizational Analysis; Powell, W.W., DiMaggio, P.J., Eds.; University of Chicago Press: Chicago, IL, USA, 1991; pp. 232-266.

31. Streeck, W.; Thelen, K. Beyond Continuity: Institutional Change in Advanced Political Economies; Oxford University Press: New York, NY, USA, 2005.

32. Hardy, C.; Maguire, S. Institutional Entrepreneurship. In The SAGE Handbook of Organizational Institutionalism; Greenwood, R., Oliver, C., Sahlin, K., Suddaby, R., Eds.; SAGE: London, UK, 2008. 
33. Battilana, J.; Leca, B.; Boxembaum, E. How Actors Change Institutions: Towards a Theory of Institutional Entrepreneurship. Acad. Manag. Ann. 2009, 3, 65-107. [CrossRef]

34. Weiss, M.; Cattaneo, C. Degrowth-Taking Stock and Reviewing an Emerging Academic Paradigm. Ecol. Econ. 2017, 137, 220-230. [CrossRef] [PubMed]

35. Sanne, C. Keynes Barnbarn: En Bättre Framtid med Arbete och Välfärd; Forskningsrådet Formas: Stockholm, Sweden, 2010.

36. Malmaeus, M. Tillväxt till Varje Pris; Notis Förlag: Malmö, Sweden, 2013.

37. Jonstad, D. Jordad-Enklare liv i Kollapsens Skugga; Ordfront: Stockholm, Sweden, 2016.

38. Statistics Sweden. 2018. Available online: http://www.statistikdatabasen.scb.se/pxweb/sv/ssd/START_ _BE_BE0101_BE0101A/BefolkningNy/table/tableViewLayout1/?rxid=0d05108d-de1b-4826-b98739cc6daf7230 (accessed on 29 March 2018).

39. The Swedish Association of Local Authorities and Regions (SKL). Kommungruppsindelning 2017: Omarbetning av Sveriges Kommuner och Landstings Kommungruppsindelning; Sveriges Kommuner och Landsting: Stockholm, Sweden, 2016.

40. The Swedish Association of Local Authorities and Regions (SKL). Classification of Swedish Municipalities 2017; Swedish Association of Local Authorities and Regions: Stockholm, Sweden, 2016.

41. Flyvbjerg, B. Five misunderstandings about case-study research. Qual. Inq. 2006, 12, 219-245. [CrossRef]

42. The Swedish Association of Local Authorities and Regions (SKL). Sweden's Democratic System; Sveriges Kommuner och Landsting: Stockholm, Sweden, 2018.

43. Sverige. Plan- och Bygglag (2010:900). Plan- och Byggförordning (2011:338); Förlagshusen: Vadstena, Sweden, 2011.

44. Brorström, S. Styra Städer-Om Strategier, Hållbarhet och Politik; Studentlitteratur: Lund, Sweden, 2015.

45. Fjertorp, J.; Larsson, R.G.; Mattisson, O. Kommunal Tillväxt: Konsten att Hantera Lokala Förutsättningar; Rapport 7; KFi tillsammans med författarna: Göteborg, Sweden, 2012; ISBN 978-91-980022-5-6.

46. Arena for Growth. Tillväxtkartor. 2018. Available online: http://www.arenafortillvaxt.se/tillvaxtkartor/\# (accessed on 29 March 2018).

47. Alingsås Kommun. Vi har en Vision. 2018. Available online: https:/ /www.alingsas.se/vision2019 (accessed on 29 March 2018).

48. Alingsås Kommun. ÖP. 1998. Available online: http://www.alingsas.se/sites/default/files/Planbeskrivning Alingsas_kommun.pdf (accessed on 29 March 2018).

49. Alingsås Kommun. Tillväxtprogram 2016-2025 för Alingsås Kommun; Alingsås Kommun: Alingsås, Sweden, 2015.

50. Bonnier, E. Framtidsveckan i Alingsås 2016; Report C 226; IVL: Stockholm, Sweden, 2017; Available online: http: / / www.ivl.se/download/18.4a88670a1596305e782422/1485961930510/C226.pdf (accessed on 6 June 2018).

51. Steg 3. 2018. Available online: https:/ / steg3bloggen.wordpress.com/ (accessed on 29 March 2018).

52. Linde, A. Bilaga 5 (Energiplanen 2011-13). In Förstudie: Alingsås Exponering mot Minskat Globalt utbud av Fossila Bränslen; Kommunledningskontoret: Alingsås, Sweden, 2011.

53. Syssner, J. Politik för Kommuner som Krymper; CKS Rapport/Linköpings Universitet, Centrum för Kommunstrategiska Studier, 2014:4; Linköpings Universitet: Linköping, Sweden, 2014.

54. Isaksson, K.; Storbjörk, S. Strategy making and power in environmental assessments. Lessons from the establishment of an out-of-town shopping centre in Västerås, Sweden. Environ. Impact Assess Rev. 2012, 34, 65-73. [CrossRef]

55. Alingsås Kommun. Protokoll Kommunstyrelsen, 2015-05-25, §§ 100-124; Kommunstyrelsen: Alingsås, Sweden, 2015; Available online: https:/ / www.alingsas.se/sites/default/files/ks_2015-05-25.pdf (accessed on 6 June 2018).

56. Olsson, J.; Hysing, E. Theorizing inside Activism: Understanding Policymaking and Policy change from Below. Plan. Theory Pract. 2012, 13, 257-273. [CrossRef]

57. Bulkeley, H.; Castán Broto, V. Urban experiments and climate change: Securing zero carbon development in Bangalore. Contemp. Soc. Sci. 2014, 9, 393-414. [CrossRef]

(C) 2018 by the authors. Licensee MDPI, Basel, Switzerland. This article is an open access article distributed under the terms and conditions of the Creative Commons Attribution (CC BY) license (http://creativecommons.org/licenses/by/4.0/). 